\title{
DECENTRALISING WAGE BARGAINING IN GERMANY - A WAY TO INCREASE EMPLOYMENT?
}

\author{
WOLFGANG OCHEL \\ CESIFO WORKING PAPER NO. 1069 \\ CATEGORY 4: LABOUR MARKETS \\ NOVEMBER 2003 \\ An electronic version of the paper may be downloaded \\ - from the SSRN website: \\ www.SSRN.com \\ - from the CESifo website: www.CESifo.de
}




\title{
DECENTRALISING WAGE BARGAINING IN GERMANY - A WAY TO INCREASE EMPLOYMENT?
}

\begin{abstract}
The area-wide wage agreement is at the centre of Germany's system of collective bargaining. In recent years, however, there has been a tendency towards the decentralisation of collective bargaining. Individual wage agreements have led to more moderate wage developments, whilst wage agreements with individual firms, and agreements at the production unit level have not had this moderating effect. On the other hand, collective bargaining has become more flexible. The further decentralisation of collective bargaining gives rise to objections based in constitutional law and to the resistance of employees and (in part) also of employers.
\end{abstract}

JEL Classification: J58, J59.

\author{
Wolfgang Ochel \\ Ifo Institute \\ Poschingerstr. 5 \\ 81679 Munich \\ Germany \\ ochel@ifo.de
}




\section{Introduction}

In May 2003 there were 4.3 million persons officially declared to be unemployed in Germany. This is an unemployment rate of 10.5 percent. Labour cost developments have been singled out as being the principal cause of this high unemployment. Wage agreements have not shown sufficient moderation, there is not enough differentiation between wage rates for different types of labour services, and not enough wage flexibility. The evolution of wages has been attributed amongst other things to the wage bargaining system in Germany.

Following Calmfors and Driffill (1988) and Calmfors (1993), wage bargaining systems can be classified according to whether they are conducted at the macroeconomic level, the sectoral level or the level of the individual enterprise. Traxler et al. (2001) object that the degree of centralisation is not sufficient to characterise wage bargaining systems adequately. In their view, it is necessary to take into account whether the wage negotiations are coordinated, and if there is coordination, what form it takes. In this context one should distinguish between horizontal and vertical coordination. Horizontal coordination aims at synchronizing wage bargaining across branches and trades. Besides the wage negotiations carried out by the umbrella organisations (i.e. employers association and trade union), at the central level there may be coordination between members of the umbrella organisations, as well as participation of the state in wage bargaining. What is more, sectoral wage settlements may be oriented to the results in a leading sector, which represents another element of coordination (pattern bargaining). Vertical coordination is directed at passing down the results obtained at a central level to lower levels (e.g. individual enterprises or production units) (Moene et al. 1993).

In the German wage bargaining system, it is usually the metal-working industry that exercises a leading role. Here negotiations begin as a rule in the area of North Württemberg and North Baden, where such successful enterprises as Daimler-Chrysler, Porsche and others are located. The wage settlement obtained for this area of the country and this sector of the economy provides an orientation mark for wage 
negotiations in virtually all other branches and regions. Legal provisions together with the structure of employers associations both work together to bring about a strong integration of the individual enterprise in sectoral wage bargaining. Nevertheless, at the level of the enterprise, collective wage agreements are also concluded.

Recent years have seen a decentralisation of wage bargaining in Germany. Area-wide collective wage agreements (Flächentarifverträge) are no longer as important as they once were, whilst company-wide collective wage agreements [Firmentarifverträge], wage agreements at the plant level [Betriebsvereinbarungen], as well as individual wage contracts have gained in importance. This decentralisation is due to changes in the basic conditions of the economy connected with globalisation, with new forms of organisation of work, etc. The decline in the power of trade unions, which prefer the area-wide wage agreement, has contributed to this development. In addition, in the face of step-wise growing unemployment, the scientific community increasingly has called for decentralisation of wage bargaining (Council of Economic Advisors, various years). There have also been recommendations that an end to union scales as a basis for labour remuneration would be desirable and would contribute to increasing employment.

The question is whether a decentralisation of wage bargaining would increase employment in Germany. In order to answer this question it is necessary not only to examine the effects of a decentralisation on wage developments. At the same time, it is also necessary to look at the productivity effects that such a reform would bring about. Apart from the efficiency analysis, it is also important to discuss whether the proposed decentralisation is in the interest of the enterprises, the employees, and their respective organisations. In addition, in evaluating the chances of achieving decentralisation, one must take into account the power position of the employers associations and of the trade unions, and hence their opportunities to resist such a decentralisation. Then too, the question must be addressed whether constitutional norms are opposed to decentralisation. But before turning to these questions, the German wage bargaining system will be described and the erosion of its most important component, the areawide collective wage agreement, will be discussed. 


\section{The German System of Wage Bargaining}

In the Federal Republic of Germany, the freedom of collective bargaining (Tarifautonomie) obtains. Trade unions, on the one hand, and employers associations or individual enterprises, on the other, negotiate and agree upon binding contracts that regulate labour remuneration and other conditions of employment. The legal basis of the freedom of collective bargaining is article 9, paragraph 3 of the German Constitution together with the Collective Agreements Act (Tarifvertragsgesetz). Contracts between a trade union and an employers association are referred to as area-wide collective wage agreements. They are for the most part made at the regional level and for individual branches of the economy. If a trade union and an individual enterprise are the collective bargaining parties, then it is referred to as a company-wide collective wage agreement. At the end of 2002, 7063 enterprises had entered into 24,542 company-wide collective wage agreements. At the same time there were 32,782 area-wide collective wage agreements (Federal Ministry of Economics and Labour 2003).

A collective wage agreement is legally binding when the employing enterprise is either a member of an association, or a party in its own right to such an agreement, and when the employee is a member of the trade union which is a party to the agreement. If the agreement is declared to be generally binding by the competent ministry, then it applies to all employees of the enterprise irrespective of their membership in the trade union and to all enterprises irrespective of their membership in an association (according to the scope of the extension). And finally, the binding nature of the contract can be agreed upon individually between employer and employee. This is usually done by employers who are members of the contracting association with respect to their employees who are not members of the trade union concerned. For employment which is subject to a collective wage agreement, the wages agreed upon - the so-called union scales represent the minimum remuneration.

The collective wage agreement continues in effect even after an enterprise gives up its membership in the employers association. The Collective Agreements Act lays down that the binding nature of the collective wage agreement is not affected by the employer leaving the association, but remains in force until the agreement expires. Thereafter, the legal norms of the agreement continue in force until a new agreement is reached. However, the collective wage agreement is deprived of its obligatory effect, so that the possibility of contractual arrangements affecting the employment relationship to the detriment of the employee are opened up (Brox and Rüthers 2002). 
According to the Collective Agreements Act, deviations from the collective wage agreement are only allowed when the modification is to the advantage of the employee, e. g. when a remuneration is agreed upon that is higher than the union scale (so-called principle of advantage [Günstigkeitsprinzip]), or when the collective wage agreement contains an 'opt-out clause' (Öffnungsklausel). In most cases, such 'opt-out clauses' give the parties at the level of the individual enterprise or the individual production unit authority to settle such questions in the context of an agreement at the plant level, that is to say an agreement between management and the representative body of the employees (the works council). Basically, one can distinguish four categories of 'opt-out clauses':

- Hardship clauses (Härtefallklauseln): such clauses provide that the employer and the works council can apply to the collective bargaining parties for permission to negotiate a special contract in order to prevent an impending insolvency, to preserve jobs, or to improve the chances of restoring the economic viability of the enterprise.

- 'Opt-out clauses' conditioned on approval by the collective bargaining parties: such contractual clauses open up the possibility for an agreement at the plant level which deviates from the collective wage agreement, but such deviating agreements do not become valid without the consent of the collective bargaining parties.

- 'Opt-out clauses' without such a condition which provide for the possibility of agreement at the plant level without the requirement of consent by the collective bargaining parties.

- Clauses permitting exceptions to small production units allowing individual contractual arrangements between employer and employee providing for remuneration below union scale as fixed in the collective wage agreement (Schnabel 2000).

Contractual 'opt-out clauses' applying to remuneration have begun to play a more important role since the middle of the 1990s; they make it possible to take into account the interests of individual enterprises or production units. Such arrangements at the plant level must be voluntarily agreed upon by management and works councils and coercive measures such as strike or lock-out are not permitted.

Absent contractual 'opt-out clauses', questions bearing on remuneration or working conditions in general which are either settled in the collective wage agreement or, although not settled, would normally be settled in the collective wage agreement, cannot be the object of agreements at the plant level ( $\S 77$, section 3 of the Industrial 
Constitution Act [Betriebsverfassungsgesetz]). Even an enterprise that is not a party to a collective wage agreement cannot negotiate with its works council on wage rates, since these lie in the jurisdiction of the collective bargaining parties, i. e. the employers association and the trade union (barrier to regulatory activity - Regelungssperre). (Such an enterprise can, however, negotiate wage agreements with individual employees.)

\section{The External Erosion of the Area-wide Collective Wage Agreements}

The relevance of area-wide collective wage agreements is determined by the degree to which they have a binding effect on the remuneration of labour or on working conditions. The proportion of production units or of employees whose remuneration or other working conditions are regulated by collective wage agreements (collective bargaining coverage) sheds light on this question.

The collective bargaining coverage can be evaluated based on data taken from the panel of production units maintained by the Institute for Employment Research of the Federal Employment Services (Bundesanstalt für Arbeit). The panel is made up of a permanent group of participants taken from production units from all branches of the economy having at least one employee subject to social security contributions. Participants are requested to supply information and the panel results are projected on the economy as a whole on the basis of employment data.

In 2002, just 44 percent of West German production units were subject to area-wide collective wage agreements, while only 20 percent of East German production units were subject to such agreements. The highest proportion of production units subject to such wage agreements were to be found in the following branches: territorial and social security authorities; mining and power production; construction industry; and banking and insurance. For almost three percent of production units in the Länder of the former Federal Republic, and five and a half percent of production units in the new Länder, company-wide collective wage agreements applied (table 1).

If one looks at the figures for employees (instead of production units), the extent to which collective wage agreements apply is larger in each case. In 2002, around 63 percent of West German employees and 43 percent of East German employees worked in a production unit which was subject to an area-wide collective wage agreement. For nearly eight percent of West German employees and just under twelve percent of East German employees, a company-wide collective wage agreement applied (table 1). 
Table 1:

Collective Bargaining Coverage in West Germany and in East Germany ${ }^{\mathrm{a}}, 2002$

\begin{tabular}{|c|c|c|c|c|c|c|c|c|}
\hline \multirow{3}{*}{ Branch } & \multicolumn{4}{|c|}{$\begin{array}{c}\text { Production unit } \\
\text { Collective wage agreement }\end{array}$} & \multicolumn{4}{|c|}{$\begin{array}{c}\text { Employees } \\
\text { Collective wage agreement }\end{array}$} \\
\hline & \multicolumn{2}{|c|}{ Area-wide } & \multicolumn{2}{|c|}{ Company-wide } & \multicolumn{2}{|c|}{ Area-wide } & \multicolumn{2}{|c|}{ Company-wide } \\
\hline & West & East & West & East & West & East & West & East \\
\hline Agriculture, etc. & 45.0 & 11.3 & 1.7 & 0.8 & 58.8 & 21.3 & 2.4 & 5.2 \\
\hline Mining/Power Production & 52.3 & .. & 9.3 & .. & 66.7 & .. & 27.0 & .. \\
\hline Primary industries & 46.7 & 21.6 & 3.3 & 5.3 & 71.6 & 39.4 & 7.3 & 14.8 \\
\hline Investment goods & 38.4 & 17.4 & 2.7 & 4.2 & 64.9 & 29.8 & 9.1 & 13.2 \\
\hline Consumer goods & 53.9 & 21.6 & 2.3 & 3.3 & 69.8 & 33.1 & 6.0 & 10.4 \\
\hline Construction industry & 66.2 & 26.9 & 0.8 & 4.1 & 79.1 & 35.4 & 2.1 & 9.6 \\
\hline Commerce/Repair & 46.8 & 19.7 & 1.6 & 3.3 & 63.6 & 35.5 & 4.1 & 5.6 \\
\hline Transport/Communication & 30.7 & 9.1 & 9.0 & 5.1 & 50.8 & 24.6 & 14.6 & 36.1 \\
\hline Banking/Insurance & 59.9 & 26.7 & 1.2 & 2.1 & 86.4 & 81.6 & 4.7 & 4.1 \\
\hline Services for enterprise & 16.8 & 12.1 & 0.4 & 4.4 & 30.6 & 34.9 & 4.0 & 7.6 \\
\hline Other services & 45.5 & 16.3 & 2.7 & 4.3 & 60.7 & 43.3 & 7.8 & 12.0 \\
\hline Non-profit organisations & 50.7 & 42.2 & 5.3 & 13.2 & 56.3 & 30.7 & 10.6 & 21.2 \\
\hline $\begin{array}{l}\text { Territorial/Soc. Security } \\
\text { authorities }\end{array}$ & 83.0 & 87.9 & 9.9 & 5.9 & 86.3 & 90.7 & 9.9 & 8.5 \\
\hline Total & 44.1 & 20.2 & 2.4 & 4.2 & 62.9 & 42.7 & 7.1 & 11.8 \\
\hline
\end{tabular}

Source: Institute for Employment Research, Panel of Production Units, Survey 10 West, Survey 7 East, 2002.

The fact that both in West and in East Germany the proportion of employees subject to an area-wide collective wage agreement is greater than that of the production units points to a situation in which larger production units are more likely to be subject to an area-wide or a company-wide agreement. This is confirmed by the figures presented in table 2, which show that both area-wide and company-wide agreements apply more frequently to medium and large size enterprises than to small enterprises. 


\section{Table 2:}

Proportion of Production Units Subject to Collective Wage Agreements by Size of Unit $^{\mathrm{a}}, \mathbf{2 0 0 2}$

\begin{tabular}{|l|c|c|c|c|}
\hline \multirow{2}{*}{$\begin{array}{l}\text { Employees } \\
\text { (on 30 June 2002) }\end{array}$} & \multicolumn{2}{|c|}{ Area-wide agreement } & Company-wide agreement \\
\cline { 2 - 5 } & West & East & West & East \\
\hline 1 to 9 & 39.4 & 16.2 & 1.7 & 2.7 \\
10 to 49 & 54.8 & 30.0 & 3.5 & 7.9 \\
50 to 199 & 62.6 & 46.4 & 7.4 & 15.4 \\
200 to 499 & 70.1 & 60.9 & 11.7 & 18.7 \\
500 or more & 82.1 & 72.2 & 9.1 & 18.7 \\
\hline Total & 44.1 & 20.2 & 2.4 & 4.2 \\
\hline a Proportion of production units for which the wage agreement applies, in percent. \\
\hline
\end{tabular}

Source: Institute for Employment Research, Panel of Production Units, Survey 10 West, Survey 7 East, 2002.

Econometric studies have shown that the probability that an area-wide collective wage agreement will be applicable is larger when the production unit has existed for a longer period and when it does not have the legal form of a proprietorship or partnership, in which the principal (or principals) has (have) the desire to intervene personally in fixing the remuneration of their employees. Other variables that have an influence are the union density and the existence of a works council. In production units in which highly qualified employees predominate, the remuneration of each employee will typically be fixed in an individual contract between employee and employer. Such employees do not as a rule see trade unions as adequate representatives of their interests and production units with a large proportion of such employees will seldom be subject to a collective wage agreement. If, however, skilled workers with a high degree of unionisation characterise the production unit, then it is more likely to be subject to a collective wage agreement (Franz and Pfeiffer 2001; Kohaut and Schnabel 2003).

The application of area-wide collective wage agreements in Germany shows a clear downward tendency. A number of factors may have contributed to this external erosion of area-wide wage agreements. As a result of the globalisation of the economy it is no longer so important to establish equality of competitive conditions at the national level for enterprises through area-wide wage agreements. On the contrary, enterprises need sufficient wage flexibility in order to be able to meet foreign competition. Furthermore, 
new and more differentiated forms of organising work require possibilities to vary remuneration at the level of the production unit. In order to avoid being subject to areawide collective wage agreements, more and more enterprises leave the employers associations, or do not join them in the first place. The decline in union density also contributes to the loss of importance of area-wide wage agreements. And finally, structural changes, in which sectors covered by collective wage agreements lose ground to those sectors in which such agreements are less likely to apply, also contribute to the erosion of area-wide collective wage agreements.

The data taken from the panel maintained by the Institute for Employment Research also indicate a decline in the importance of area-wide collective wage agreements. For West Germany, these data go back to 1995, and for East Germany to 1996. In West Germany, in 199572.2 percent of employees were subject to an area-wide wage agreement, in 2002 this proportion had declined to 62.9 percent. In East Germany, a decline from 56.3 percent in 1996 to 42.7 percent in 2002 has been registered (cf. Figure 1). Looking at production units, the decline in units subject to area-wide wage agreements amounted to almost nine percentage points in West Germany and five and a half percentage points in East Germany. The shrinking importance of wage agreements covering entire branches of the economy is only one dimension of the erosion of areawide collective wage agreements; there is also an internal erosion which reinforces the tendencies which have just been described.

\section{The Internal Erosion of Area-wide Collective Wage Agreements}

Whilst the external erosion of the importance of area-wide collective wage agreements has been measured with reference to their formal relevance for the remuneration of labour, the concept of the internal erosion of such agreements refers to their decreasing relevance of standards laid down in area-wide collective wage agreements as a way of shaping or standardising working conditions in areas in which such agreements are binding on production units. One can distinguish between two forms of internal erosion of area-wide wage agreements: contractual flexibilisation and breach of contract. Deviations from the formally valid norms of the wage agreement which have not been imposed unilaterally by management, but which have been the object of (re-)negotiation within the production unit, represent measures of contractual flexibilisation. The collective bargaining parties may or may not participate directly in the negotiations leading to such flexibilisation agreements. One may speak of breach of contract when a production unit is in a legal sense subject to a collective agreement, but the management 
unilaterally, though with some implicit support by employees, decides not to observe the norms laid down in that agreement (Artus 2001, pp. $111 \mathrm{ff}$. and $125 \mathrm{ff}$.).

\section{Figure 1:}

\section{Employees Subject to Area-wide Collective Wage Agreements ${ }^{\text {a }}$}

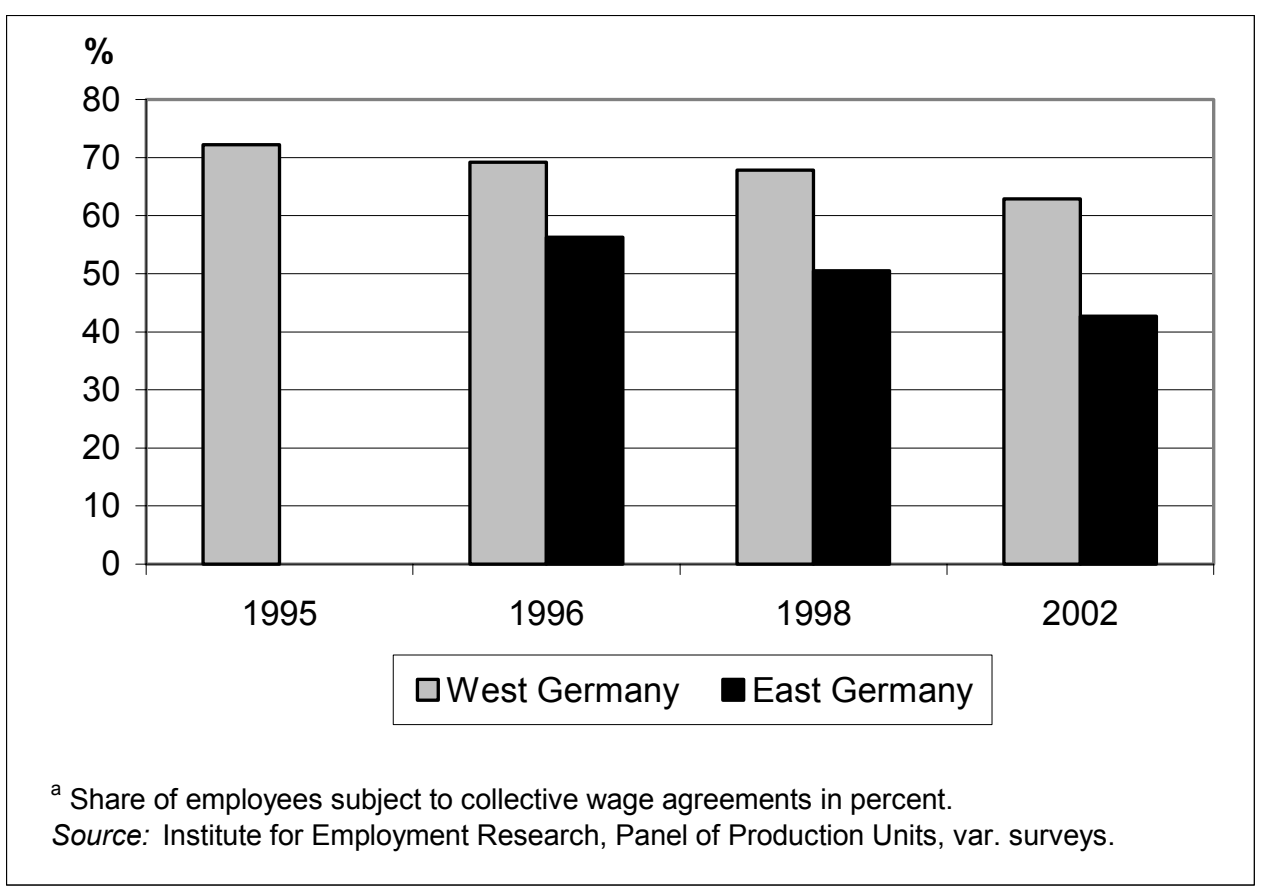

Although the collective bargaining parties exercise a considerable influence in cases of flexibilisation agreed upon by them, this type of flexibilisation, nevertheless, contributes to an erosion of the system of area-wide wage agreements. There are two approaches to this kind of flexibilisation: making use of 'opt-out clauses' and - as already mentioned above - the conclusion of company-wide collective wage agreements. Contractual 'optout clauses' have become rather wide-spread in Germany. There are very few wagesettlement areas in which 'opt-out clauses' have not been agreed upon. The survey of works and personnel councils carried out by the WSI ${ }^{1}$ showed that in 200235 percent of the production units and 22 percent of state authorities made use of contractual 'opt-out clauses'. In 1999/2000, only 22 percent of the production units took advantage of them.

1 The survey of works and personnel councils carried out by the Economic and Social Science Institute (Wirtschafts- und Sozialwissenschaftliches Institut [WSI]) in the Hans Böckler Foundation collects and analyses information obtained from members of works councils in production units, and from members of personnel councils in state authorities; production units and government authorities employing more than 20 persons in all areas of the economy and in all branches of government are surveyed. In West Germany more than 46 percent of these units have a council, in East Germany the parallel figure is 40 percent. The survey was carried out in 1997/98, 1999/2000 and 2002. 
These clauses have been applied mainly with respect to the regulation of working hours. But with respect to questions of pay they were also referred to in no less than one-sixth of the production units and government offices. The exceptions often took the form of lower pay scales for persons entering employment (Einstiegstarife) as well as of cuts in, or elimination of, yearly special payments (Bispinck 2001, Bispinck and Schulten 2003). They are used more often in East Germany than in West Germany. In East Germany, in settling questions of remuneration the works councils bring in the trade unions much less often than in West Germany (Artus 2001, pp. 129 - 30; Artus, Schmidt and Sterkel 2000).

In addition to these legal ways there are also illegal forms of contractual flexibilisation. Measures of flexibilisation settled at the plant level are illegal when works council and management come to an agreement permitting deviation from currently valid wage agreements without the involvement of the collective bargaining parties. This may take the form of an agreement at the plant level (Betriebsvereinbarung) or a regulatory agreement (Regelungsabrede). No information is available concerning the extent or frequency of such agreements.

Contractual 'opt-out clauses' are often the basis for "alliances for employment" at the production unit level (betriebliche Bündnisse für Arbeit). But these alliances may include other forms of agreements, some of which are illegal as well. The basic idea underlying these alliances is a bartering arrangement: the employees make concessions with respect to remuneration and the employer promises to maintain a certain level of employment for a limited period of time (Seifert 2002). In the WSI survey for 2002, 29 percent of works councils and 23 percent of personnel councils had internal agreements meant to ensure a given level of employment or the survival of the production unit or government office. The share of large production units (with more than 1000 employees) having such arrangements is 46 percent and it is clearly higher than the average (Bispinck and Schulten 2003; Hassel and Rehder 2001).

Apart from the contractual flexibilisation measures, breach of contract contributes to the internal erosion of the area-wide wage agreement as well. According to information collected from works councils in the WSI survey, in 2002 ten percent of production units occasionally failed to meet the standards established in collective wage agreements; five percent reported that they often failed to meet these standards. In East Germany, violations of the collective agreements occur more frequently than in West Germany. In enterprises owned by the state or in government authorities, collective agreements are in general observed (Bispinck and Schulten 2003). Bahnmüller (2002) 
comes to similar conclusions in a survey of managers and members of works councils in production units subject to a collective wage agreement in the engineering industry, the textile and garment industry and the banking sector. His survey indicates that ten percent of the production units deviate considerably from the area-wide wage agreement. In 37 percent of the production units the deviations are considered to be insignificant, whilst 53 percent of the production units observe the agreement punctiliously.

This internal erosion of collective wage agreements reinforces the external erosion in Germany. In 2002, we have seen that around 63 percent of West German employees and 43 percent of their east German colleagues worked in a production unit that was subject to an area-wide wage agreement; seven respectively twelve percent worked in production units that had company-wide collective wage agreements. It is, however, not possible to give precise figures regarding the proportion of employees that are paid below the scales agreed upon in these agreements, since representative figures showing the extent of internal erosion of area-wide agreements are not available. The WSI surveys indicate, however, that the cases of remuneration falling short of the norms established in collective agreements are not negligible. On the other hand, the influence of collective wage agreements goes beyond the area in which they are in a formal sense binding. The remuneration of labour in production units not subject to such agreements is in many cases nonetheless influenced by union pay scale. Results for 2002 obtained from the panel of the Institute for Employment Research show that 30 percent of employees in West Germany and 45 percent in East Germany are not covered by a collective wage agreement. However, in both parts of the country more than half of these employees are covered indirectly by a collective wage agreement, since the production unit where they work fixes remuneration according to union scales (Kohaut and Schnabel 2003).

\section{The Macroeconomic Connection Between the Degree of Centralisation of Wage Bargaining and Employment}

The wage bargaining system must fulfil three criteria in order to make a positive contribution to employment. The system should ensure that when full employment prevails, the wage increases are in line with macroeconomic productivity developments. If there is less than full employment, then wage increases should lie below productivity increases. In addition, the system of wage negotiation should permit sufficient wage 
flexibility so that the economy can respond appropriately to macroeconomic shocks. Furthermore, the system should make possible wage differentials that correspond to market conditions. And finally, the system of wage negotiations should function in such a way that employees are encouraged to perform optimally.

The degree of centralisation of wage bargaining exercises its influences on the development of labour remuneration principally through two mechanisms: the internalisation of external wage effects and the exploitation of market power (Calmfors et al. 2001; Berthold and Fehn 1996). The corporatist thesis is based entirely on internalisation effects. Collective bargaining parties that have a central frame of reference, i.e. that see the wage determination problem in a macroeconomic context, will be more likely to take into account the macroeconomic implications of wage negotiations and hence will tend to moderate wage settlements. The more decentralised the wage negotiations are, the less wage externalities will be internalised. In this view, the straight line marked $\mathrm{I}$ in figure 2 sketches the relationship between degree of centralisation and moderation of wage settlements.

The hump-shape thesis developed by Calmfors and Driffill (1988) takes into account not only the internalisation effects, but also the differences in the possibilities of price setting that are connected with wage increases. The individual production unit has little room to pass on wage increases to its customers in the form of price increases, since the high elasticity of substitution on the demand side between its own products and those of its competitors means that price increases for its products will result in a falling off in the demand for its output. At the level of the entire branch, however, the possibility to pass on wage increases is greater, since all competing enterprises are affected equally by the wage increase, and customers cannot so easily shift their demand to other branches (the elasticity of substitution between the products of different branches being low). At the macroeconomic level, the negative effects of excessive wage increases cannot be passed on to others (figure 2).

Many comparative empirical studies come to the conclusion that a high degree of centralisation of wage bargaining (with its high degree of horizontal coordination) leads to a greater moderation in the development of the real wage level than decentralised wage negotiations with scant coordination (Calmfors et al. 2001). ${ }^{2}$ The comparison of a

\footnotetext{
2 For Blanchard and Wolfers (2000) and Nicoletti et al. (2001), the superiority of highly centralised wage bargaining systems is not based on moderate wage increases resulting from them, but rather on the greater wage flexibility as compared to systems with less coordination. In their view, coordinated wage
} 
system with intermediate centralisation with a system of scant centralisation does not, however, give such clear cut results. If internalisation mechanisms are the primary influence at work, then decentralisation will lead to higher increases in wages. If, on the other hand, the mechanisms underlying the hump-shaped curve are dominant, then the decentralisation will result in a decrease in the growth of real wages.

\section{Figure 2:}

\section{Degree of Centralisation of Wage Bargaining and Real Wages}

Real wage

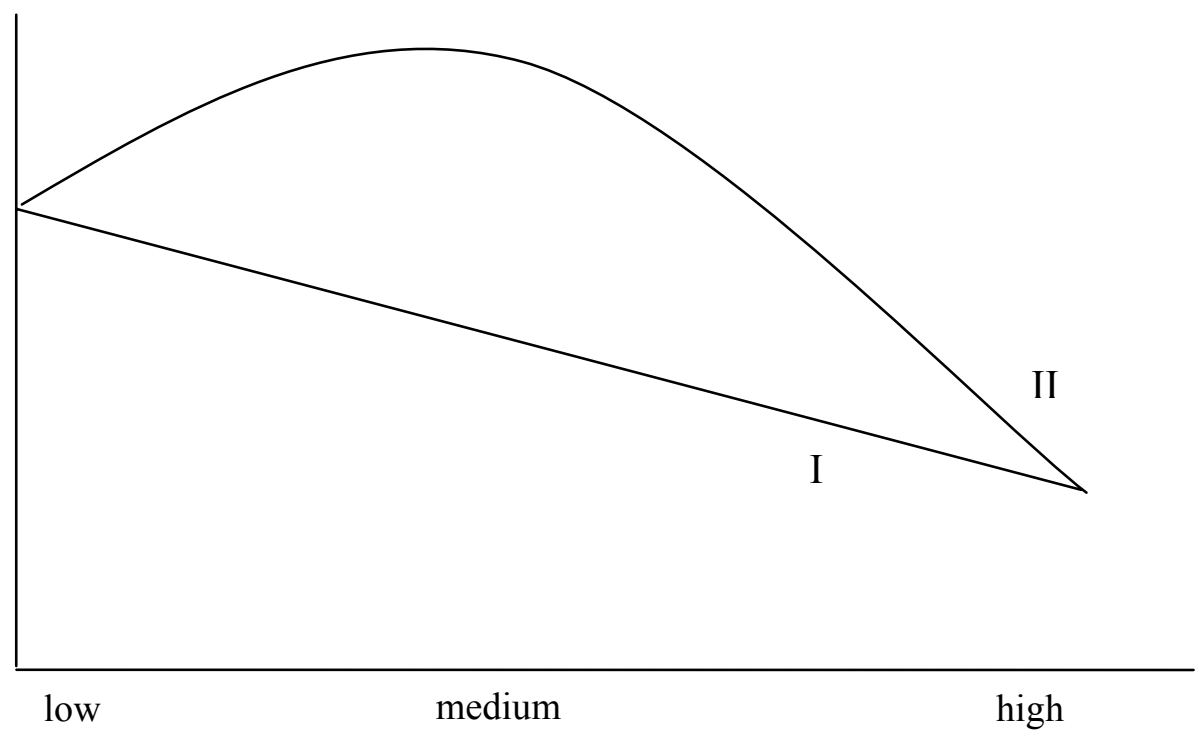

Degree of centralisation

I Corporatism

II Hump shape

The relationship between the degree of centralisation and wage developments presented here is the "classical" concept, which for a number of reasons has been called into question in recent years. Traxler (2003) accepts the superiority of centralised bargaining systems only with qualifications. In his view, in evaluating systems of wage negotiations the coordination of wage negotiations must be taken into account along with the degree of centralisation. According to Traxler, centralised wage negotiations are advantageous only when the state takes measures that ensure that settlements made at the centralised level are accepted by the members of the collective bargaining parties

negotiations are able to react appropriately to macroeconomic shocks and are thus better able to prevent unemployment from increasing 
at lower levels (vertical coordination). Otherwise, there is the risk that wage increases at the level of the individual firm will run counter to the macroeconomic coordination of wage developments.

In addition, the coordination form of pattern bargaining must also be considered in evaluating systems of wage negotiations with a medium degree of centralisation. Pattern bargaining is the most important single element of the German system of wage negotiations. In almost all regions and branches, the wage agreements are to a greater or lesser degree oriented to the wage agreements reached in the mental-working industry in North Württemberg and North Baden where extremely profitable enterprises are located. This results in a tendency for wage agreements in economically weaker regions to be "excessive". In order to represent the full effect of this tendency graphically, the hump-shaped curve in figure 2 would have to show greater kurtosis.

The hump-shape thesis, according to which area-wide collective wage agreements are inferior to company-wide collective agreements with respect to wage moderation has, however, been questioned by Fitzenberger and Franz (1999). In their view, the determination of the optimal degree of centralisation must also take into account the insider-outsider problem. They suggest that insider behaviour is particularly important at the level of the production unit, since the influence of the jobholders (especially those with higher qualifications) is stronger there than at the level of the trade union organisation. This implies that decentralised wage negotiations would for that reason not lead to more moderate wage settlements if compared to more centralised negotiations.

Wage bargaining systems cannot be evaluated without considering the interaction with other areas of state decision making. As soon as these are taken into consideration, conclusions may be inverted, and decentralised negotiations may turn out to be more advantageous. For example, Iversen (1999) has been able to show that, in conjunction with a medium degree of centralisation of wage negotiations, monetary policy oriented to defending price stability will lead to a considerable reduction in unemployment, while in conjunction with a high degree of centralisation it will on the contrary act to increase unemployment.

Theoretical and empirical research shows that a majority of macroeconomists holds the opinion that a high degree of centralisation in wage negotiations brings about the most advantageous wage and employment development from a macroeconomic point of view. However, a number of liberal economists challenge this opinion. They argue that 
centralised wage negotiations tend to off-set market forces in the labour market, traditional wage agreements being thought of as a sort of cartel arrangement. As a consequence, wage rates agreed upon are higher than the rates that would clear the labour market. Furthermore, the structure of wage rates agreed upon in such agreements would show a higher degree of compression than would be the case in competitive markets (Möschel 1996; Siebert 1997).

\section{Wage Bargaining Systems as Seen by the Production Unit}

In the preceding section, wage bargaining systems with different degrees of centralisation were examined with respect to their macroeconomic effects. But the individual production unit (plant) will look at a bargaining system mainly in terms of how well the system fits to its economic needs. Today, a production unit must be competitive on an international level. Technical progress has led to the abandonment of the Taylor approach to the design of production processes which has been predominant for such a long time. New market conditions and different production processes require that the individual employee should take more responsibility and that he or she should be able to deal with a greater range of tasks (Lindbeck and Snower 2001). The formation of human capital that is specific to the firm is increasingly a decisive factor on which the success of an enterprise depends.

Speaking in general terms it is very difficult for centralised wage bargaining to respond adequately to the specific requirements of individual production units. The bargaining parties are confronted with information problems. They are unable to evaluate sufficiently the situation of individual production units (Freeman and Gibbons 1993). What is more, collective wage agreements are usually standardised and are not capable of rewarding individual performance adequately. This increases the risk that labour performance will remain under the attainable level. Furthermore, the wage agreements may undermine the incentives for the individual employees to develop their human capital. Wage determination at the production unit level is better suited to solve the problems relating to asymmetric information and incentives. Wage agreements at the production unit level can take into consideration the economic situation of the unit and the ability of the employees; such agreements can be designed to meet the problems and the requirements that are specific to a particular unit.

In the context of the German wage bargaining system, it is, however, in large measure already possible for the production unit to remunerate, adequately and individually, 
employees who take on more demanding tasks or accumulate human capital that is specific to the firm. Collective wage agreements only establish minimum conditions and there is no reason why enterprises should not pay above these minimum requirements (principle of advantage).

Although decentralised wage negotiations offer the advantages of greater flexibility, they also entail problems. Bargaining gives rise to transaction costs. Wage contracts agreed upon in centralised wage negotiations reduce these transaction costs, particularly for production units with a relative homogenous staff or with standardised working conditions. Moreover, if centralised wage negotiations bring about uniform conditions throughout a particular branch, this tends to reduce the mobility of labour between production units, since wage differentials will be reduced, thus diminishing turnover costs.

A further disadvantage of wage bargaining at the plant level is that it shifts the conflicts related to bargaining down to the production unit level; this can lead to losses in productivity. As well, decentralised wage negotiations generally increase the frequency of strikes. This is related to the fact that when compared to the management, the employees of an enterprise are usually less able to assess the economic situation of the enterprise. As a consequence they tend to overestimate the scope for wage increases. Management is inclined to represent the economic situation in an unfavourable light, and since the employees will be aware of this, they will be tempted to resort to a strike in order to determine their employer's true willingness to accept a settlement and to impose the corresponding wage increases. In centralised wage negotiations, the trade union and the employers association have approximately the same information basis with respect to macroeconomic developments, and a strike as an information revealing device is less likely to be employed.

Whilst from a macroeconomic point of view central (i.e. highly coordinated) wage bargaining appears to be more advantageous, from a microeconomic point of view there is much to be said in favour of wage negotiations at the level of the production unit or for individual agreements between employer and employee. (Both positions are, however, controversial.) The German system seeks to combine wage negotiations with a medium degree of centralisation (pattern bargaining) with decentral elements (company-wide collective wage agreements, contractual 'opt-out clauses' opening the way for agreements at the plant level, individual agreements between employer and employee). In this way it attempts to further income distribution objectives whilst at the same time it seeks to take advantage of coordination advantages and also to provide the flexibility needed by individual business enterprises or plants. The empirical studies 
reviewed in the next section shed light on the success obtained in balancing these objectives.

\section{Collective Agreements and Wages in Germany}

Up till now, the influence of collective wage agreements on wage levels and on productivity has scarcely been studied empirically for Germany. The studies done by Pfeiffer (2003), the survey of enterprises carried out by the Centre for European Economic Research (Zentrum für Europäische Wirtschaftsforschung [ZEW]) (Franz et al. 2000) and the surveys of works councils and personnel councils of the WSI (Bispinck and Schulten 2003) are exceptions to this statement. In addition, there are a few further studies on selected aspects of the subject. Pfeiffer examines the extent to which wage rigidity exists and whether existing rigidities are the result of union scales or whether they have been accepted by enterprises in the interest of ensuring efficiency. His study is based on wage data obtained from the employment sample of the Institute for Employment Research in the period 1975 to 1995 . The ZEW survey is based on a survey of 801 enterprises in industry and services which was carried out in the spring of 2000. The survey sought to determine the reasons for insufficient flexibility of remuneration. The survey of works and personnel councils carried out by the WSI amongst other things was meant to assess the shifting of wage bargaining to the production units by the members of these councils.

For Pfeiffer, wage rigidity exists when in comparison to a state defined as being flexible (i.e., wage determination under competition) wages cannot fall. They can either not decline because of union scales that have been agreed upon (rigidity of contractual scales). Or they cannot fall in nominal terms because of other reasons (rigidity of nominal wages). An example may clarify the method employed. Suppose that the personal and the employment characteristics of employees $\mathrm{A}$ and $\mathrm{B}$ are similar. If the actual change in A's pay during a given period corresponds exactly to the rise in the relevant union scales, and if the actual change in B's pay (under competitive conditions) is less than the rise in the union scales in the same period, then there is rigidity because of union scales. If A's pay does not change during the period under review, whilst B's pay (under competitive conditions) declines, then there is rigidity of nominal wages. In order to determine the number of employees whose pay exhibits rigidity, the yearly variations in pay between employees are compared. The extent of wage rigidity is calculated from the changes in pay experienced by more than two million employees. 
For the period 1975 - 1995, Pfeiffer comes to the conclusion that in West Germany wage rigidities have protected about half of the employees either from wage changes that would have been less than the changes in the union scales that were agreed upon, or from nominal wage losses. (For the other half of the employees, their wages were variable.) Rigidities in union scales have been quantitatively more important than rigidities in nominal wages. ${ }^{3}$ During the period 1975 to 1990 the real wage level was on average six percent higher than it otherwise would have been if nominal wage rigidities had not been present. This effect may be referred to as a bloating of the wage level, and one must suppose that it has contributed to dampening the dynamics of employment in Germany. At the same time, one should take into account that induced productivity improvements are a partially compensating factor.

The importance of rigidity in contractual scales and of rigidity in nominal wages depends on the qualifications of the employees. The ZEW survey indicates that in the case of employees with low levels of qualifications, the main cause of inflexible remuneration is binding collective wage agreements, but implicit wage contracts also have an effect. With respect to the group of employees with high qualifications, the enterprise must take into account the costs of recruiting labour as well as the costs associated with the loss of human capital that will result if wages are reduced and, as a consequence, employees find employment elsewhere. In particular, the risk of losing one's best employees to other firms, and the resulting costs of recruiting and training new candidates, the loss of human capital that inevitably occurs when employees with long years of experience leave the production unit and finally the negative signalling effect that is sent out by lower pay rates with respect to recruiting new employees are emphasised as negative side effects of pay reductions (Franz et al. 2000).

In connection with the wage rigidity that is related to collective wage agreements in general, the question arises whether union wage scales that are agreed upon in company-wide collective wage agreements tend to be lower than union scales that come about as a result of area-wide collective wage agreements. According to Meyer (1992) this is not the case; Pfeiffer (2003, p. 151) comes to the conclusion that this is only exceptionally the case. Based on their theoretical analysis as well as simulations, Fitzenberger and Franz (1999) conclude that taking the insider-outsider problem into

\footnotetext{
Beissinger and Koppik (2003) have reviewed studies based on surveys, on experimental studies and microeconometric studies in a number of countries. In contrast to Pfeiffer, they come to the conclusion that downward rigidities of nominal wages are not the result of institutional arrangements, but rather of psychological factors. They argue that in the Anglo-Saxon countries there is a downward nominal wage rigidity that is comparable to continental European countries, although union density is much lower as is collective bargaining coverage.
} 
account, there is no clear ordinal difference between collective wage negotiations at the level of the firm and negotiations at the branch level. Even contractual 'opt-out clauses' and the agreements at the plant unit level that are based on such clauses would not necessarily lead to lower wages (Pfeiffer 2003, p. 157).

In comparing area-wide collective wage agreements with company-wide collective wage agreements and agreements at the plant level, it must be borne in mind that works councils, who are the main actors involved in the shift of wage bargaining to the production unit, are quite sceptical about the resulting increase in their tasks and responsibilities. The WSI survey (2002) shows that only fourteen percent of those surveyed welcomed this change, 38 percent were ambivalent, and 42 percent responded that they considered this shift to be in general problematic. There is concern that the decentralisation of wage bargaining will disturb the balance of power in favour of employers, that within a particular bargaining area, wages will drift apart, and that works councils will be confronted with problems that are beyond their power to solve (Bispinck and Schulten 2003). Wage agreements that are considered to be unfair and the introduction of distributional conflicts in the production units can have a negative affect on employees. The absorption of works councils in wage negotiations will reduce their possibilities to collaborate in measures designed to improve productivity (Hübler and Jirjahn 2001).

Company-wide collective wage negotiations and agreements at the plant level (based on contractual 'opt-out clauses') do not result in more moderate wage contracts than negotiations at the branch level. At the same time, Pfeiffer's study indicates that individual wage negotiations do lead to more moderate wage developments. Over all, wages negotiated individually are lower than those agreed upon in collective negotiations. It is too early to assess whether free competition in determining wage rates provides favourable incentives for performance, or whether it rather tends to reduce workers' motivation and willingness to perform optimally, since the effects of free wage agreements on performance and motivation have not yet been studied.

\section{Proposals for a Further Decentralisation of Wage Bargaining}

In the German debate two major steps for a further decentralisation of wage bargaining have been proposed. These steps would have the effect of cutting back the influence of trade unions in the process of wage determination. One idea is that individual wage negotiations should have greater importance than is today the case. Wage competition at 
the level of the individual production unit or the individual worker should be strengthened by abolishing the freedom of collective bargaining guaranteed in the German Constitution. On the one hand, the realisation of this proposal would result in a reduction in wage bloating, but at the same time it would be accompanied by an increase in transaction costs, a loss of services provided by associations, a decrease of countervailing power of trade unions etc. The abolition of the freedom of collective bargaining would require a two-thirds majority in the German parliament and it would be difficult to obtain the broad base support such a majority requires; in particular, one would have to expect considerable resistance on the part of employees enjoying an insider position.

A second way to broaden the area of individual wage negotiations is for enterprises to leave employers associations. This is already taking place. However, trade unions' power and employees' militancy will set limits to this process. Wherever union density and the militancy of union members are high, the enterprise runs the risk of conflicts which will represent a disadvantage vis-à-vis competitors without labour relations problems. Under such circumstances employers will prefer to stay in (or re-enter) the employers association and stick to the area-wide wage agreement. In this way, the individual enterprise is protected against measures arising from labour conflicts that affect it alone.

A third way to extend the range of individual wage agreements is for government to make use of its statutory authority. It could contribute to the reduction of collective bargaining coverage by abolishing extension laws, or at least by making the legal requirements for such extensions more restrictive, for example by defining under what conditions there is a "public interest" ( $§ 5$, sect. 1 of the Collective Agreement Act) in extending collective agreements. In addition, the length of time in which the old wage agreement is still binding after the employer has left the employers association could be reduced. ${ }^{4}$ These changes in the institutional framework of wage determination are advisable.

4 A reduction in the legally binding force of wage agreements could be brought about if the principle of advantage would be given a different interpretation by the legislature and the courts. Under the currently valid interpretation, this principle forbids deviations from the collective wage agreement when wage concessions are proposed in return for greater job security, for instance in the form of a commitment by the employer to refrain from redundancies based on the general economic situation of the production unit. It is a matter of controversy whether it is desirable and legally admissible to introduce considerations of job security in applying the principle of advantage in specific cases (cf. the annual report of the Council of Economic Advisors, 2002/2003, §§ 467 and 468). 
In addition to broadening the area of individual wage negotiations there are calls for trade union influence to be curtailed by enacting legal provisions which make possible wage agreements at the production unit level; the proposal is to provide a legal basis for this by means of statutory "opt-out clauses". Most of the proposals along these lines suggest that a quorum should be the precondition for making use of such a clause, requiring the approval of the management of the enterprise, a majority of votes under the employees and - in some proposals - also agreement of the works council. In addition, the possibilities for agreements at the plant level with employers who are not subject to area-wide wage agreements should be liberalised, which requires a change in $\S 77$, sect. 3 of the Industrial Constitution Act (Betriebsverfassungsgesetz) concerning the restrictions on possible agreements relating to wages and conditions of work etc. (modification of the barrier to regulatory activity).

Statutory 'opt-out clauses' as well as the modification of the Industrial Constitution Act will in all likelihood meet with objections based on constitutional law. For one thing, such clauses interfere with the freedom of collective wage bargaining. They also undermine the freedom of choice of the individual (and hence the basic right to private autonomy) with respect to the right to negotiate his or her remuneration with the employer. This autonomy is impaired by the fact that organisations without legitimation (management of the enterprise/works councils) conclude wage agreements that are binding on the individual. Limitation of the freedom of collective wage bargaining would, however, seem to be justified under certain circumstances, when other basic rights such as the right to work (in a situation of mass unemployment) are affected. In weighting the different types of violations of basic rights, agreements at the plant level which contain wage schedules for newly hired employees who were formerly long-term unemployed or wage reductions as a measure to save jobs in a production unit threatened by insolvency are considered legally permissible (Möschel 2003). ${ }^{5}$

If there is a shift in favour of agreements at the plant level, then on the one hand wage determination will be made more flexible. On the other hand, the system of area-wide collective wage agreements will be undermined. As more and more enterprises enter into agreements at the plant level, the pressure on other enterprises to follow suit will become greater. The balance of the dual system of wage bargaining would be put at

\footnotetext{
In view of the reservations based on considerations of constitutional law that have been formulated with respect to binding wage agreements at the plant level that are grounded in statutory 'opt-out clauses', Möschel (2003) proposes that the employees in such a production unit be asked individually to accept as binding the model agreements that have been worked out by the management and the works council. At the same time, the employer should have under certain circumstances, the right to give notice to an employee who refuses to accept the model agreement.
} 
risk. The decentralisation of wage bargaining would also mean that coordination resulting from pattern bargaining would be abolished; this type of coordination has contributed up till now to a reduction of wage competition between production units and to a greater degree of social peace, as expressed in fewer strikes. In the future, it would be possible that wage competition between enterprises will become more intense as a result of the changes in the institutional conditions. In the service of reducing wage rigidities, this would be entirely desirable, but on the other hand it could lead to more frequent strikes. The traditional mechanisms of coordination would no longer be able to make the same contribution to maintaining social peace; business enterprises would have to assume responsibility for this task (Hassel and Rehder 2001; Streeck and Rehder 2003).

A statutory decentralisation of wage bargaining would bring about more moderate wage agreements compared to agreements where unions are involved. However, the wage agreements emerging from such bargaining will in all likelihood not be moderate enough to bring about a sustained reduction in unemployment. There are two reasons for this. One is that the Constitution sets limits to this form of decentralisation of wage bargaining. The other is that most of the available evidence indicates that agreements at the production unit level do not generally lead to more moderate wage agreements, although it must be noted that up till now information is limited to agreements that have come about as a result of contractual 'opt-out clauses'.

Since the extension of individual wage agreements is debatable and runs up against limits, and since the acceptance of plant level agreements on the basis of statutory "optout clauses" represents risks, one could consider other measures to ensure that the collective bargaining parties reach more moderate agreements and greater wage dispersion. A more binding obligation to support the attainment of social objectives such as high levels of employment could be imposed on the collective bargaining parties. This could follow the pattern of the Netherlands, where a foundation ("Stichting van de Arbeid") prepares wage negotiations and points out the labour market consequences of imminent wage agreements. It would also make sense to broaden the spectrum of issues dealt with in collective negotiations; in this way the importance of distributional conflict might be reduced and their solution could be made easier (Streeck 1998).

Wage agreements providing for moderate wage increases could also be attained by weakening the power of insiders, e.g. by reforming employment protection laws. Furthermore, the narrowing of the wedge which the high social security contributions 
drive between gross wages and net earnings could contribute to employees' willingness to accept agreements which provide only a moderate increase in gross wages (Franz 2002). An increase in women's participation in gainful employment would have the same effect, since if there are two earners in a household, this makes it easier to renounce wage increases. Then too, more wage disparity could be sought for. This could be brought about by reducing the level and the duration of entitlement of social benefits so as to reduce the reservation wage rates. The positive effect on employment and the social tolerance of such measures could be enhanced if they are accompanied by wage tax credits for employees in low wage groups (Sinn et al. 2002).

\section{Summary}

The area-wide collective wage agreement is at the centre of the German system of wage bargaining. In recent years, however, there has been some decentralisation of wage bargaining. The area-wide agreement has declined in importance and wage agreements at lower, i.e. more decentralised, levels (company-wide collective wage agreements, agreements at the plant level, individual wage contracts) have correspondingly gained ground.

Empirical studies indicate that the decentralisation of collective wage bargaining (company-wide collective agreements instead of area-wide agreements) has up till now not led to more moderate wage agreements. The same applies with respect to agreements at the plant level (based on contractual 'opt-out clauses') vis-à-vis area-wide collective agreements, although wage flexibility has been increased. In contrast, in individual wage agreements lower wages are agreed upon than in collective agreements. Collective agreements serve in particular to protect less qualified employees against a deterioration in their wages. There is no information permitting a conclusion with respect to whether free wage competition leads to more favourable incentives to employees' performance.

In Germany, the freedom of collective wage bargaining guaranteed in the Constitution is an obstacle to reinforcing individual wage determination, as is the readiness of employees to defend the system of collective wage negotiations. Some of the legal obstacles that stand in the way of reducing collective bargaining coverage could, however, be removed. A statutory decentralisation of wage bargaining through agreements at the plant level most probably would bring about a minor moderation in wage developments and an increase in wage flexibility. However, objections on 
constitutional and socio-economic grounds arise and, hence, there are limitations to the spread of this form of decentralisation. In any case, a further flexibilisation of the system of area-wide wage agreements is desirable, without putting the dual system of wage bargaining at risk. In addition, other complementary labour market institutions and the social security system should be reformed in order to reach more moderate wage agreements and a greater wage dispersion. 


\section{References}

Artus, I. (2001), Krise des deutschen Tarifsystems, Wiesbaden.

Artus, I., R. Schmidt and G. Sterkel (2000), Brüchige Tarifrealität. Der schleichende Bedeutungsverlust tariflicher Normen in der ostdeutschen Industrie, Berlin.

Bahnmüller, R. (2002), "Diesseits und jenseits des Flächentarifvertrags, Entgeltfindung und Entgeltstrukturen in tarifgebundenen und nicht tarifgebundenen Unternehmen", Industrielle Beziehungen 9 (4), 402 - 424.

Beissinger, T. and C. Knoppik (2003), „Sind Nominallöhne starr? Neuere Evidenz und wirtschaftspolitische Implikationen, IZA Discussion Paper No. 800, June.

Berthold, N. and R. Fehn (1996), „Evolution von Lohnverhandlungssystemen - Macht oder ökonomisches Gesetz?", in: W. Zohlnhöfer (ed.), Die Tarifautonomie auf dem Prüfstand, Berlin, 57 - 94.

Bispinck, R. (2001), „Betriebliche Interessenvertretung, Entgelt und Tarifpolitik“, WSI Mitteilungen 2, $124-132$.

Bispinck, R. and T. Schulten (2003), „Verbetrieblichung der Tarifpolitik? Aktuelle Tendenzen und Einschätzungen aus Sicht von Betriebs- und Personalräten“, WSI Mitteilungen 3, $157-166$.

Blanchard, O. and J. Wolfers (2000), "The Role of Shocks and Institutions in the Rise of European Unemployment: The Aggregate Evidence", Economic Journal 110, C1-33.

Brox, H. and B. Rüthers (2002), Arbeitsrecht, Stuttgart.

Bundesministerium für Wirtschaft und Arbeit (2003), Tarifvertragliche Arbeitsbedingungen im Jahr 2002, Berlin.

Calmfors, L. and J. Driffill (1988), "Bargaining Structure, Corporatism and Macroeconomic Performance", Economic Policy 6, 14 - 61.

Calmfors, L. (1993), "Centralisation of Wage Bargaining and Macroeconomic Performance”, OECD Economic Department Working Paper 131, Paris.

Calmfors, L., A. Booth, M. Burda, A. Checchi, R. Naylor and J. Visser (2001), „The Future of Collective Bargaining in Europe“, in: T. Boeri, A. Brugiavini and L. Calmfors (eds.), The Role of Unions in the Twenty-First Century, Oxford, 1-151.

Fitzenberger, B. and W. Franz (1999), „Der Flächentarifvertrag: Eine kritische Würdigung aus ökonomischer Sicht", in: W. Franz, H. J. Ramser and M. Stadler (eds.), Ökonomische Analyse von Verträgen, Tübingen, 191 - 232. 
Franz, W. (2002), „Für mehr Beschäftigung: Was jetzt zu tun ist", ZEW news Extra, September.

Franz, W., M. Gutzeit, J. Lessner, W. A. Oechsler, F. Pfeiffer, L. Reichmann, V. Rieble and J. Roll (2000), Flexibilisierung der Arbeitsentgelte und Beschäftigungseffekte. Ergebnisse einer Unternehmensbefragung, Mannheim, ZEW-Dokumentation 00 - 90.

Franz, W. and F. Pfeiffer (2001), „Tarifbindung und ökonomische Rationalität von Lohnrigiditäten“, ZEW Discussion Paper No. 01-01, Mannheim.

Freeman, R. and R. Gibbons (1993), "Getting Together and Breaking Apart: The Decline of Centralized Collective Bargaining", NBER Working Paper 4464.

Hassel, A. and B. Rehder (2001), „Institutional Change in the German Wage Bargaining System - The Role of Big Companies“, Max Planck Institute for the Studies of Societies, Working Paper 01/9.

Hübler, O. and J. Jirjahn (2001), "Work Councils and Collective Bargaining in Germany: The Impact on Productivity and Wages", IZA Discussion Paper 332.

Iversen, T. (1999), Contested Economic Institutions, The Politics of Macroeconomics and Wage Bargaining in Advanced Democracies, Cambridge.

Kohaut, S. and C. Schnabel (2003), „Zur Erosion des Flächentarifvertrags: Ausmaß, Einflussfaktoren und Gegenmaßnahmen“, Industrielle Beziehungen 10 (2), 193 - 219.

Lindbeck, A. and D. J. Snower (2001), “Centralized Bargaining and Reorganized Work: Are They Compatible?”, European Economic Review 45, 1851 - 1875.

Meyer, W. (1992), “Abschlussebene und Lohndynamik. Eine vergleichende empirische Analyse von Firmen- und Branchentarifabschlüssen”, Zeitschrift für Wirtschafts- und Sozialwissenschaften (ZWS) 112 (1), 59 - 74.

Moene, K. O., M. Wallerstein and M. Hoel (1993), „Bargaining Structure and Economic Performance“, in: R. J. Flanagan, K. O. Moene and M. Wallerstein (eds.), Trade Union Behaviour, Pay-Bargaining, and Economic Performance, Oxford, 65 131.

Möschel, W. (1996), "Tarifautonomie - ein überholtes Ordnungsmodell?”, in: W. Zohlnhöfer (ed.), Die Tarifautonomie auf dem Prüfstand, Berlin, 11 - 23.

Möschel, W. (2003), Decentralized Determination of Wages and the Freedom of Collective Bargaining, Tübingen, mimeo.

Nicoletti, G., R. Haffner, S. Nickell, S. Scarpetta and G. Zoegi (2001), "European Integration, Liberalization and Labour Market Performance", in: G. Bertola, T. Boeri and G. Nicoletti (eds.), Welfare and Employment in a United Europe, Cambridge, Mass., $147-235$. 
Pfeiffer, F. (2003), Lohnrigiditäten in gemischten Lohnbildungssystemen, Schriftenreihe des ZEW Bd. 65, Baden-Baden.

Sachverständigenrat zur Begutachtung der gesamtwirtschaftlichen Entwicklung (Council of Economic Experts) (var. y.), Jahresgutachten, Wiesbaden.

Schnabel, C. (2000), Tarifautonomie und Tarifpolitik, Cologne.

Seifert, H. (2002), „Betriebliche Bündnisse für Arbeit - Beschäftigen statt entlassen“, in: H. Seifert (ed.), Betriebliche Bündnisse für Arbeit, Rahmenbedingungen, Praxiserfahrungen, Zukunftsperspektiven, Berlin, 65 - 85.

Siebert, H. (1997), "Labor Market Rigidities - At the Root of Unemployment in Europe", Journal of Economic Perspectives 11, 37 - 57.

Sinn, H. W., Ch. Holzner, W. Meister, W. Ochel and M. Werding (2002), “Aktivierende Sozialhilfe. Ein Weg zu mehr Beschäftigung und Wachstum", ifo Schnelldienst 9, 3 52.

Streeck, W. (1998), „Das Zukunftsmodell - der Flächentarifvertrag“, Gewerkschaftliche Monatshefte 1, 6-18.

Streeck, W. and B. Rehder (2003), „Der Flächentarifvertrag: Krise, Stabilität und Wandel“, MPIfG Working Paper 03/6, Juli.

Traxler, F. (2003), "Bargaining (De)centralization, Macroeconomic Performance and Control over the Employment Relationship”, British Journal of Industrial Relations 41 (1), March, $1-27$.

Traxler, F., S. Blaschke and B. Kittel (2001), National Labour Relations in Internationalized Markets, Oxford. 


\section{CESifo Working Paper Series}

(for full list see www.cesifo.de)

1005 Burkhard Heer, Nonsuperneutrality of Money in the Sidrauski Model with Heterogeous Agents, August 2003

1006 V. Anton Muscatelli, Piergiovanna Natale, and Patrizio Tirelli, A Simple and Flexible Alternative to the Stability and Growth Pact Deficit Ceilings. Is it at hand?, August 2003

1007 Reto Foellmi and Josef Zweimüller, Inequality and Economic Growth: European Versus U.S. Experiences, August 2003

1008 James S. Costain and Michael Reiter, Business Cycles, Unemployment Insurance, and the Calibration of Matching Models, August 2003

1009 Marco Runkel, Optimal Contest Design when the Designer's Payoff Depends on Competitive Balance, August 2003

1010 Donald O. Parsons, Torben Tranaes and Helene Bie Lilleør, Voluntary Public Unemployment Insurance, August 2003

1011 Rüdiger Pethig and Andreas Wagener, Profit Tax Competition and Formula Apportionment, August 2003

1012 Johan Willner, Privatisation and Public Ownership in Finland, August 2003

1013 Seppo Kari and Jouko Ylä-Liedenpohja, Taxation and Valuation of International Real Investments, August 2003

1014 James Heckman, Rosa Matzkin and Lars Nesheim, Simulation and Estimation of Hedonic Models, August 2003

1015 Biswa N. Bhattacharyay, Towards a Macro-Prudential Leading Indicators Framework for Monitoring Financial Vulnerability, August 2003

1016 J. Stephen Ferris and Stanley L. Winer, Searching for Keynes: With Application to Canada, 1870-2000, August 2003

1017 Massimo Bordignon, Luca Colombo and Umberto Galmarini, Fiscal Federalism and Endogenous Lobbies' Formation, August 2003

1018 Annette Alstadsæter, The Dual Income Tax and Firms' Income Shifting through the Choice of Organizational Form and Real Capital Investments, August 2003

1019 Peter Fredriksson and Bertil Holmlund, Optimal Unemployment Insurance Design: Time Limits, Monitoring, or Workfare?, August 2003 
1020 Kashif S. Mansori, Following in their Footsteps: Comparing Interest Parity Conditions in Central European Economies to the Euro Countries, August 2003

1021 Christoph Borgmann and Matthias Heidler, Demographics and Volatile Social Security Wealth: Political Risks of Benefit Rule Changes in Germany, August 2003

1022 Kjell Erik Lommerud, Bjørn Sandvik and Odd Rune Staume, Good Jobs, Bad Jobs and Redistribution, August 2003

1023 Patrick Karl O'Brien, The Governance of Globalization: The Political Economy of Anglo-American Hegemony, 1793-2003, September 2003

1024 Antonio Ciccone and Giovanni Peri, Skills' Substitutability and Technological Progress: U.S. States 1950-1990, September 2003

1025 Bjørn Sandvik, Optimal Taxation and Normalisations, September 2003

1026 Massimo Bordignon and Gilberto Turati, Bailing Out Expectations and Health Expenditure in Italy, September 2003

1027 José A. Herce, Namkee Ahn, Ricard Génova, and Joaquín Pereira, Bio-Demographic and Health Aspects of Ageing in the EU, September 2003

1028 John Komlos and Marieluise Baur, From the Tallest to (One of) the Fattest: The Enigmatic Fate of the American Population in the $20^{\text {th }}$ Century, September 2003

1029 Stefan Napel and Mika Widgrén, Bargaining and Distribution of Power in the EU's Conciliation Committee, September 2003

1030 Kai Li and Dale J. Poirier, Relationship Between Maternal Behavior During Pregnancy, Birth Outcome, and Early Childhood Development: An Exploratory Study, September 2003

1031 Ivar Ekeland, James J. Heckman, and Lars Nesheim, Identifcation and Estimation of Hedonic Models, September 2003

1032 Kjetil Bjorvatn and Alexander W. Cappelen, Decentralization and the Fate of Minorities, September 2003

1033 Lars-Erik Borge and Jørn Rattsø, The Relationships Between Costs and User Charges: The Case of a Norwegian Utility Service, September 2003

1034 Maureen Were and Nancy N. Nafula, An Assessment of the Impact of HIV/AIDS on Economic Growth: The Case of Kenya, September 2003

1035 A. Lans Bovenberg, Tax Policy and Labor Market Performance, September 2003

1036 Peter Birch Sørensen, Neutral Taxation of Shareholder Income: A Norwegian Tax Reform Proposal, September 2003 
1037 Roberta Dessi and Sheilagh Ogilvie, Social Capital and Collusion: The Case of Merchant Guilds, September 2003

1038 Alessandra Casarico and Carlo Devillanova, Capital-skill Complementarity and the Redistributive Effects of Social Security Reform, September 2003

1039 Assaf Razin and Efraim Sadka, Privatizing Social Security Under Balanced-Budget Constraints: A Political-Economy Approach, September 2003

1040 Michele Moretto, Paolo M. Panteghini, and Carlo Scarpa, Investment Size and Firm's Value under Profit Sharing Regulation, September 2003

1041 A. Lans Bovenberg and Peter Birch Sørensen, Improving the Equity-Efficiency Tradeoff: Mandatory Savings Accounts for Social Insurance, September 2003

1042 Bas van Aarle, Harry Garretsen, and Florence Huart, Transatlantic Monetary and Fiscal Policy Interaction, September 2003

1043 Jerome L. Stein, Stochastic Optimal Control Modeling of Debt Crises, September 2003

1044 Thomas Stratmann, Tainted Money? Contribution Limits and the Effectiveness of Campaign Spending, September 2003

1045 Marianna Grimaldi and Paul De Grauwe, Bubbling and Crashing Exchange Rates, September 2003

1046 Assar Lindbeck and Dennis J. Snower, The Firm as a Pool of Factor Complementarities, September 2003

1047 Volker Grossmann, Firm Size and Diversification: Asymmetric Multiproduct Firms under Cournot Competition, September 2003

1048 Dan Anderberg, Insiders, Outsiders, and the Underground Economy, October 2003

1049 Jose Apesteguia, Steffen Huck and Jörg Oechssler, Imitation - Theory and Experimental Evidence, October 2003

1050 G. Abío, G. Mahieu and C. Patxot, On the Optimality of PAYG Pension Systems in an Endogenous Fertility Setting, October 2003

1051 Carlos Fonseca Marinheiro, Output Smoothing in EMU and OECD: Can We Forego Government Contribution? A Risk Sharing Approach, October 2003

1052 Olivier Bargain and Nicolas Moreau, Is the Collective Model of Labor Supply Useful for Tax Policy Analysis? A Simulation Exercise, October 2003

1053 Michael Artis, Is there a European Business Cycle?, October 2003

1054 Martin R. West and Ludger Wößmann, Which School Systems Sort Weaker Students into Smaller Classes? International Evidence, October 2003 
1055 Annette Alstadsaeter, Income Tax, Consumption Value of Education, and the Choice of Educational Type, October 2003

1056 Ansgar Belke and Ralph Setzer, Exchange Rate Volatility and Employment Growth: Empirical Evidence from the CEE Economies, October 2003

1057 Carsten Hefeker, Structural Reforms and the Enlargement of Monetary Union, October 2003

1058 Henning Bohn and Charles Stuart, Voting and Nonlinear Taxes in a Stylized Representative Democracy, October 2003

1059 Philippe Choné, David le Blanc and Isabelle Robert-Bobée, Female Labor Supply and Child Care in France, October 2003

1060 V. Anton Muscatelli, Patrizio Tirelli and Carmine Trecroci, Fiscal and Monetary Policy Interactions: Empirical Evidence and Optimal Policy Using a Structural New Keynesian Model, October 2003

1061 Helmuth Cremer and Pierre Pestieau, Wealth Transfer Taxation: A Survey, October 2003

1062 Henning Bohn, Will Social Security and Medicare Remain Viable as the U.S. Population is Aging? An Update, October 2003

1063 James M. Malcomson, Health Service Gatekeepers, October 2003

1064 Jakob von Weizsäcker, The Hayek Pension: An efficient minimum pension to complement the welfare state, October 2003

1065 Joerg Baten, Creating Firms for a New Century: Determinants of Firm Creation around 1900 , October 2003

1066 Christian Keuschnigg, Public Policy and Venture Capital Backed Innovation, October 2003

1067 Thomas von Ungern-Sternberg, State Intervention on the Market for Natural Damage Insurance in Europe, October 2003

1068 Mark V. Pauly, Time, Risk, Precommitment, and Adverse Selection in Competitive Insurance Markets, October 2003

1069 Wolfgang Ochel, Decentralising Wage Bargaining in Germany - A Way to Increase Employment?, November 2003 